\title{
PROCESS OPTIMIZATION AND BIOSORPTION OF LEAD USING ALBIZIA SAMAN LEAF POWDER
}

\begin{abstract}
Water pollution is one of the signs that humans have exceeded the limits and causing health problems for living beings on earth. The present paper comprises the optimization and biosorption of lead from aqueous solution using Albizia saman leaf powder as biosorbent. Single Step Optimization was considered for preliminary runs with the variables agitation time, biosorbent size, $\mathrm{pH}$ of the solution, initial concentration of the aqueous solution, dosage of biosorbent and temperature. The Central Composite Design (CCD) was used for final runs optimization using Response Surface Methodology (RSM). Results indicated that the optimum agitation time for biosorption of lead is $50 \mathrm{~min}$. The increase in mass of biosorbent lead to increase in lead $(\mathrm{pb})$ ion biosorption due to the increase in the number of active biosorption sites. Maximum percentage biosorption is observed at a $\mathrm{pH}$ of 6 and with particle size of $53 \mu \mathrm{m}$. Experimental data were better described by pseudosecond-order model. The adsorption isotherm could be well fitted by the Langmuir equation followed by Freundlich and Temkin. Over and all, Albizia Saman leaf powder can be used as an effective natural biosorbent for the economic treatment of aqueous solutions containing lead.
\end{abstract}

Rao, P.J ${ }^{1}$, Kumari, R.S ${ }^{1}$,Babji J.S ${ }^{2}$, Naga Lakshmi, N.V.R ${ }^{3}$ and Raju, Ch.A.I. ${ }^{{ }^{*}}$

${ }^{\prime}$ Department of Chemical Engineering, Andhra University, Visakhapatnam - 530003

${ }^{2}$ Department of Computer Science and Systems Engineering, Andhra University, Visakhapatnam - 530003

${ }^{3}$ Department of Petroleum Engineering, GIET College of Engineering, Rajahmundry

$\underline{\text { Keywords - Albizia Saman, biosorption, optimization, isotherms, kinetics }}$

\section{INTRODUCTION}

Because of its relative recent development in the planet's history, pollution is a human problem. Before the 19th century Industrial Revolution, people lived more in harmony with their immediate environment. If one or more substances have built up in resources like water, air etc., to such an extent that they cause problems for living beings, we treat it as polluted one. As industrialization has spread around the globe, the problem of pollution spread along with it. Intensive mining operations and processing of minerals to meet the increasing needs of our society have led to environmental pollution in specific locations all over the world [1]. Heavy metals are discharged from various industries such as electroplating, plastic manufacturing, textile, storage batteries, mining and metallurgical process [2]. Water pollution of toxic heavy metal ions discharged from the industries and inhabited areas is seriously harmful to the health of human beings and the eco-system. Among these heavy metals, lead may be the severe pollutant sources due to its wide applications in industries, which may produce wastewater containing lead at the concentrations higher than the recommended doses of $0.015 \mathrm{mg} / \mathrm{L}$. Microorganisms immobilized on natural and synthetic adsorbents have been used for separation and preconcentration of heavy metals at trace levels $[3,4,5,6,7]$. Most studies have focused on the removal of $\mathrm{Pb}^{2+}, \mathrm{Cd}^{2+}$, and $\mathrm{Ni}^{2+}$ from wastewater by using various biosorbents [8]. Biosorbents are prepared from the naturally abundant or waste biomass of algae, moss, fungi or bacteria [9]. Hence the naturally and abundantly available albizia saman has been selected for the present study for the removal of lead from aqueous solutions.

\section{MATERIALS AND METHODS}

\subsection{Biosorbent Preparation}

Albizia saman leaves were obtained from Rajahmundry. The leaves are washed thrice with tap water and once with distilled water in order to remove adhering mud, impurities etc. It was dried in sunlight for one week until all the moisture was evaporated. The crispy powder were then crushed and grinded to powder, separated using British Standard Sieves (BSS) and stored in dry vacuum packs to prevent moisture content and readily used as biosorbent.

\subsection{Batch sorption studies}

Preliminary experiments were conducted in $250 \mathrm{ml}$ Erlenmayer flasks containing $50 \mathrm{ml}$ of $20 \mathrm{mg} / \mathrm{L}$ metal solution using single step optimization procedure. The flasks were agitated on an orbital shaker at $180 \mathrm{rpm}$ and samples were taken at predetermined time intervals $(1,3,5,10,15,20,25,30,40,50,60,90,120,150 \& 180 \mathrm{~min}) \&$ centrifuged at $14000 \mathrm{rpm}$ and the supernatant liquid was analysed in Atomic Absorption Spectrophotometer (AAS) for final concentrations. Similarly the other variables were varied in a wide range: Biosorbent Size $(53,75,104,125 \& 152 \mu \mathrm{m}), \mathrm{pH}$ of the aqueous solution $(2,3$, 4, 5, 6, 7 and 8), Initial concentration of lead solution (25, 30, 60, $120 \& 180 \mathrm{mg} / \mathrm{L})$, Biosorbent Dosage (10, 20, 30, 40, 50 \& $60 \mathrm{~g} / \mathrm{L})$ and Temperature $(283,293,303,313 \& 323 \mathrm{~K})$.

\subsection{Process optimization}


Final experimental runs for optimization were obtained through Response Surface Methodology from Design of Experiments (DoE) using STATISTICA software. The extent of biosorption of lead calculated at the preliminary optimum conditions is verified with the final runs for the optimum conditions.

\section{RESULTS AND DISCUSSION}

The potential of dry Albizia saman leaf powder as a biosorbent for the biosorption of lead metal present in an aqueous solution is investigated in the present investigation. The effects of various parameters on biosorption of lead are studied. The numerical analysis of the investigation was undertaken applying CCD using RSM.

\subsection{Effect of agitation time}

The equilibrium agitation time is determined by plotting the \% biosorption of lead against agitation time as shown in fig. 1. For $0.5 \mathrm{~g}(10 \mathrm{mg} / \mathrm{L})$ of biosorbent and $53 \mu \mathrm{m}$ of biosorbent size in the interaction time intervals of 1 to $180 \mathrm{~min} 58.30 \%$ $(1.166 \mathrm{mg} / \mathrm{g})$ of lead is biosorbed in the first $1 \mathrm{~min}$. The \% biosorptionis increased briskly up to 50 min reaching $79.45 \%$ $(1.589 \mathrm{mg} / \mathrm{g})$. Beyond $50 \mathrm{~min}$, the $\%$ biosorption is constant indicating the attainment of equilibrium conditions. The maximum biosorption of $79.45 \%(1.589 \mathrm{mg} / \mathrm{g})$ is attained for $50 \mathrm{~min}$ of agitation time with $10 \mathrm{~g} / \mathrm{L}$ of $53 \mu \mathrm{m}$ size biosorbent mixed in $50 \mathrm{~mL}$ of aqueous solution $\left(\mathrm{C}_{0}=20 \mathrm{mg} / \mathrm{L}\right)[10,11]$.

\subsection{Effect of biosorbent size}

The percentage biosorption is increased from $72.12(1.4424 \mathrm{mg} / \mathrm{g})$ to $79.45 \%(1.589 \mathrm{mg} / \mathrm{g})$ as the biosorbent size decreases from 152 to $53 \mu \mathrm{m}$ presented in fig. 2. This phenomenon is expected, as the size of the particle decreases, surface area of the biosorbent increases; thereby the numbers of active sites on the biosorbent are better exposed to the biosorbate.

\subsection{Effect of $\mathrm{pH}$ of the aqueous solution}

In order to determine the optimal value, $\mathrm{pH}$ of the aqueous solution is varied from 2 to 8 . The $\mathrm{pH}$ of aqueous solution is shown against \% biosorption of lead in fig 3 . The \% biosorption of metal is increased from $58.42 \%(1.1684 \mathrm{mg} / \mathrm{g})$ to $77.18 \%(1.5436 \mathrm{mg} / \mathrm{g})$ as $\mathrm{pH}$ is increased from 2 to 6 and decreased beyond $\mathrm{pH}$ value of 7 . The predominant sorbing forms of lead are $\mathrm{Pb}^{2+}$ and $\mathrm{PbOH}^{+}$that occurr in the $\mathrm{pH}$ range of 4-6. This is the reason for higher biosorption of lead in the $\mathrm{pH}$ range of 4-6. At $\mathrm{pH}$ higher than 6, precipitation of lead occurred and biosorption due to biosorption is reduced [12, 13, $14]$.

\subsection{Effect of initial concentration of lead in the aqueous solution}

The effect of initial $\mathrm{Pb} 2+$ ion concentration is investigated in the range of $20-180 \mathrm{mg} / \mathrm{L}$. The effect of initial concentration of lead in the aqueous solution on the percentage biosorption of lead is shown in fig. 4. The percentage biosorption of lead is decreased from $77.12 \%$ to $58.68 \%$ with an increase in C0 from $20 \mathrm{mg} / \mathrm{L}$ to $180 \mathrm{mg} / \mathrm{L}$ while the uptake capacity is increased from 1.5424 to $10.5624 \mathrm{mg} / \mathrm{g}$ [15].

\subsection{Effect of biosorbent dosage}

The biosorption of lead increases from $77.14 \%(1.5428 \mathrm{mg} / \mathrm{g})$ to $83.78 \%(0.5585 \mathrm{mg} / \mathrm{g})$ with an increase in biosorbent dosage from 10 to $30 \mathrm{~g} / \mathrm{L}$, shown in fig. 5. Such behavior is obvious because with an increase in biosorbent dosage, the number of active sites available for lead biosorption would be more. The change in percentage biosorption of lead is marginal from $83.78 \%(0.5585 \mathrm{mg} / \mathrm{g})$ to $84.92 \%(0.2830 \mathrm{mg} / \mathrm{g})$ when ' $\mathrm{w}$ ' is increased from 30 to $60 \mathrm{~g} / \mathrm{L}$. Hence all other experiments are conducted at $30 \mathrm{~g} / \mathrm{L}$ dosage.

\subsection{Effect of temperature}

The effect of temperature on the equilibrium metal uptake was significant. The effect of changes in the temperature on the lead uptake is shown in fig. 6. When temperature was lower than $303 \mathrm{~K}$, Lead uptake increased with increasing temperature, but when temperature was over $303 \mathrm{~K}$, the results slowed down and the increase is marginal. This response suggested a different interaction between the ligands on the cell wall and the metal. Below $303 \mathrm{~K}$, chemical biosorption mechanisms played a dominant role in the whole biosorption process, biosorption was expected to increase by increase in the temperature. While at higher temperature, the plant powder was in a nonliving state, and physical biosorption became the main process. Physical biosorption reactions were normally exothermic, thus the extent of biosorption generally is constant with further increasing temperature [16]. 
IOSR Journal of Pharmacy

Vol. 2, Issue 3, May-June, 2012, PP.579-592

\subsection{Isotherms}

\subsubsection{Langmuir isotherm}

Irving Langmuir developed an isotherm named as Langmuir isotherm, which is the most widely used simple twoparameter equation. Langmuir isotherm is drawn between $\mathrm{Ce}$ vs $\mathrm{Ce} / \mathrm{qe}$ shown in fig 7 . The equation obtained is $(\mathrm{Ce} / \mathrm{qe})=$ $2.8729 \mathrm{Ce}+0.05929$ with a good linearity (correlation coefficient, $\mathrm{R} 2=0.9791)$ indicating strong binding of lead ions to the surface of albizia saman leaf powder. The separation factor (RL) of 0.9219 shows favorable biosorption $(0<\mathrm{RL}<1)$. Hence a maximum biosorption capacity of the Albizia saman leaf powder for lead is find to be $16.8656 \mathrm{mg} / \mathrm{g}$ by Langmuir isotherms at $303 \mathrm{~K}$ (mass of biosorbent: $10 \mathrm{~g} / \mathrm{L}$ ) [17, 18].

\subsubsection{Freundlich isotherm}

Freundlich empirical adsorption isotherm equation can be applied in case of low and intermediate concentration ranges. Freundlich isotherm is drawn between $\log \mathrm{q}_{\mathrm{e}}$ and $\log \mathrm{C}_{\mathrm{e}}$, in fig. 8 The equation obtained is $\log \mathrm{q}_{\mathrm{e}}=0.6815 \log \mathrm{C}_{\mathrm{e}}-$ 0.2404. The resulting equation has a correlation coefficient of 0.9655 . The ' $\mathrm{n}$ ' value in the above equations is 0.6815 , satisfies the condition of $0<\mathrm{n}<1$ indicating favorable biosorption. $\mathrm{K}_{\mathrm{f}}$ is $0.5748 \mathrm{mg} / \mathrm{g}$ [19].

\subsubsection{Temkin isotherm}

Temkin and Pyzhev isotherm equation describes the behavior of many adsorption systems on the heterogeneous surface. The present data are analysed according to the linear form of Temkin isotherm and the linear plot is shown in fig. 9 The equation obtained for lead biosorption is: $\mathrm{q}_{\mathrm{e}}=3.1546 \ln \mathrm{C}_{\mathrm{e}}-3.8813$ with a correlation coefficient 0.9637 . The best fit model is determined based on the linear regression correlation coefficient $\left(\mathrm{R}^{2}\right)$ [20].

\subsection{Kinetics of biosorption}

Kinetic models are used to describe the order of biosorbate - biosorbent interactions. Traditionally, the first order model of Lagergren finds wide application. In the case of biosorption preceded by diffusion through a boundary, the kinetics in most cases follows the first order rate equation of Lagergren [21]:

$\left(\mathrm{dq}_{\mathrm{t}} / \mathrm{dt}\right)=\mathrm{K}_{1}\left(\mathrm{q}_{\mathrm{e}}-\mathrm{q}_{\mathrm{t}}\right)$

where $\mathrm{q}_{\mathrm{e}}$ and $\mathrm{q}_{\mathrm{t}}$ are the amounts adsorbed at $\mathrm{t}$, min and equilibrium time and $\mathrm{K}_{\mathrm{ad}}$ is the rate constant of the first order adsorption.

The above equation can be presented as

$\log \left(\mathrm{q}_{\mathrm{e}}-\mathrm{q}_{\mathrm{t}}\right)=\log \mathrm{q}_{\mathrm{e}}-\left(\mathrm{K}_{1} / 2.303\right) \mathrm{t}$

$\log \left(\mathrm{q}_{\mathrm{e}}-\mathrm{q}_{\mathrm{t}}\right)=-0.02357 \mathrm{t}-0.3027 ; \mathrm{R}^{2}=0.9620$

Plot of $\log \left(\mathrm{q}_{\mathrm{e}}-\mathrm{q}_{\mathrm{t}}\right)$ versus ' $\mathrm{t}$ ' gives a straight line for first order kinetics, facilitating the computation of biosorption rate constant $\left(\mathrm{K}_{1}\right)$. If the experimental results do not follow the above equation, they differ in two important aspects:

$\mathrm{K}_{1}\left(\mathrm{q}_{\mathrm{e}}-\mathrm{q}_{\mathrm{t}}\right)$ does not represent the number of available adsorption sites and $\log \mathrm{q}_{\mathrm{e}}$ is not equal to the intercept.

In such cases, pseudo second order kinetic equation [22,23]:

$(\mathrm{dq} / \mathrm{dt})=\mathrm{K}_{2}(\mathrm{qe}-\mathrm{qt})^{2}$ is applicable, where ' $\mathrm{K}_{2}$ ' is the second order rate constant.

The other form of the above equation is:

$\left(\mathrm{t} / \mathrm{q}_{\mathrm{t}}\right)=\left(1 / \mathrm{K}_{2} \mathrm{qe}^{2}\right)+(1 / \mathrm{qe}) \mathrm{t}$

$\left(\mathrm{t} / \mathrm{q}_{\mathrm{t}}\right)=0.6229 \mathrm{t}+1.1720 ; \mathrm{R}^{2}=0.9959$

The pseudo second order model based on above equation, considers the rate-limiting step as the formation of chemisorptive bond involving sharing or exchange of electrons between the biosorbate and biosorbent. If the pseudo second order kinetics is applicable, the plot of $\left(\mathrm{t} / \mathrm{q}_{\mathrm{t}}\right)$ versus ' $\mathrm{t}$ ' gives a linear relationship that allows computation of $\mathrm{q}_{\mathrm{e}}$ and $\mathrm{K}_{2}$.

In the present study, the kinetics are investigated with $50 \mathrm{~mL}$ of aqueous solution $\left(\mathrm{C}_{0}=20 \mathrm{mg} / \mathrm{L}\right)$ at $303 \mathrm{~K}$ with the interaction time intervals of $1 \mathrm{~min}$ to $50 \mathrm{~min}$. Lagergren and pseudo plots for biosorption of lead with biosorbent size $53 \mu \mathrm{m}$ of Albizia saman leaf powder are drawn in figs. $10 \& 11$. As the correlation coefficient values for the pseudo second order kinetics is 0.99 which is better than first order kinetics $\left(\mathrm{R}^{2}=0.962\right)$, very well describes the biosorption mechanism of lead using Albizia saman leaf powder.

\subsection{Thermodynamics of biosorption}

The process of Biosorption is temperature dependant. In general, the temperature dependence is associated with three thermodynamic parameters namely change in enthalpy of biosorption $(\Delta \mathrm{H})$, change in entropy of biosorption $(\Delta \mathrm{S})$ and change in Gibbs free energy $(\Delta \mathrm{G})$.

The Van't Hoff's plots for the biosorption data obtained at initial concentrations of the lead are shown in fig. 12. The equation obtained is $\log \mathrm{q}_{\mathrm{e}} / \mathrm{C}_{\mathrm{e}}=-0.41701(1 / \mathrm{T})+0.5921$. The correlation coefficient is 0.9568 . In the present study, the enthalpy change is $\Delta \mathrm{H}$ is $7.9845 \mathrm{~J} / \mathrm{mole}$ is positive indicating that the biosorption is endothermic. The value of $\Delta \mathrm{S}$ is 11.3370 $\mathrm{J} /$ mole is also positive indicating the irreversibility of process, $\Delta \mathrm{G}$ is $3427.1334 \mathrm{~J} / \mathrm{mole}$ is negative indicating the spontaneity of biosorption. 
IOSR Journal of Pharmacy

Vol. 2, Issue 3, May-June, 2012, PP.579-592

\subsection{Optimization of the selected parameters using CCD}

In order to determine an optimum condition for lead ions removal, the parameters having greater influence over the response are to be identified. In the present study, the relationship between four independent variables and percent of lead ions biosorption is fitted well with the quadratic model. The regression equation for the optimization of lead biosorption: \% biosorption of lead $(Y)$ is a function of the $W\left(X_{1}\right), C_{o}\left(X_{2}\right), p H\left(X_{3}\right)$, and $T\left(X_{4}\right)$. Table-1 presents the coded levels and Table2 represents the variations in the corresponding coded values of four parameters and response based on experimental runs and predicted values proposed by CCD design.

$Y=-452.007+0.429 X_{1}+0.369 X_{2}+5.846 X_{3}+3.347 X_{4}-0.006 X_{12}-0.015 X_{22}-0.548 X_{32}-0.006 X_{42}+0.004 X_{1} X_{2}-$ $0.010 X_{1} X_{3}+0.026 X_{2} X_{3}+0.002 X_{3} X_{4}$

Interpretation of the regression analysis:

The results of above regression model for Eq. (1) (in the form of analysis of variance ANOVA) are compiled in Table-3. In general, the Fischer's ' $F$-statistics' value ( $=\mathrm{MS}_{\text {model }} / \mathrm{MS}_{\text {error }}$ ), where MS (mean square) with a low probability 'P' value indicates high significance of the regression model. The ANOVA of the regression model demonstrates that the model is highly significant, as is evident from the Fisher's $\mathrm{F}$-test $\left(\mathrm{F}_{\text {model }}=33852\right)$ and a very low probability value $\left(\mathrm{P}_{\text {model }}>\right.$ $\mathrm{F}=0.000000)$. More over, the computed F-value $\left(\mathrm{F}_{0.05}(14.15)=\mathrm{MS}_{\text {model }} / \mathrm{MS}_{\text {error }}=33852\right)$ is greater than that of the tabular Fvalue $\left(\mathrm{F}_{0.05}(14.15)\right.$ tabulars $\left.=2.42\right)$ at the $5 \%$ level, indicating that the treatment differences are significant.

The significance of the regression coefficient of the parameter can be verified by the Student's t-test as a tool, while 'P' values signify the pattern of interaction among the factors. From the Table-4, we can observe that, the larger the value of $t$ and smaller the value of $\mathrm{P}$, more significant is the corresponding coefficient term. By analyzing the ' $\mathrm{t}$ ' values and ' $\mathrm{P}$ ' values from Table-4, it is found that the $X_{1}, X_{2}, X_{3}, X_{4}, X_{1}{ }^{2}, X_{2}{ }^{2}, X_{3}{ }^{2}, X_{4}^{2} X_{1} X_{2}, X_{1} X_{3}, X_{1} X_{4}, X_{2} X_{3}, X_{2} X_{4}, X_{3} X_{4}$ have high significance to explain the individual and interaction effect of biosorption variables on the biosorption of lead to predict the response.

A positive sign of the coefficient represents a synergistic effect which means response (\% biosorption of lead increases with the increase in effect, while a negative sign indicates an antagonistic effect which means response (\% biosorption of lead) decreases with the increase in effect. The optimal set of conditions for maximum percentage biosorption of lead is $\mathrm{pH}=6.0250$, biosorption dosage $(\mathrm{w})=31.7191 \mathrm{~g} / \mathrm{L}$, initial lead concentration $\left(\mathrm{C}_{\mathrm{o}}\right)=19.8996 \mathrm{mg} / \mathrm{L}$ and temperature $=304.0673 \mathrm{~K}$. The extent of biosorption of lead calculated at these optimum conditions is $84.90612 \%$. Fig. 13 shows the comparison between the $\%$ biosorption obtained through experiments and predicted. The correlation coefficient $\left(\mathrm{R}^{2}\right)$ provides a measure of the models variability in the observed response values. The closer the $\mathrm{R}^{2}$ value to 1 , the stronger the model is and it predicts the response better. In the present study the value of the regression coefficient $\left(\mathrm{R}^{2}=0.99997\right)$ indicates that $0.003 \%$ of the total variations are not satisfactorily explained by the model. The ANOVA Table- 3 can be used to test the statistical significance of the ratio of mean square due to regression and mean square due to residual error.

Figs. 15 to 20 were represented as a function of two factors at a time, holding other factors fixed at zero level for the Interaction effects of biosorption variables. 
IOSR Journal of Pharmacy

Vol. 2, Issue 3, May-June, 2012, PP.579-592

\section{FIGURES AND TABLES}

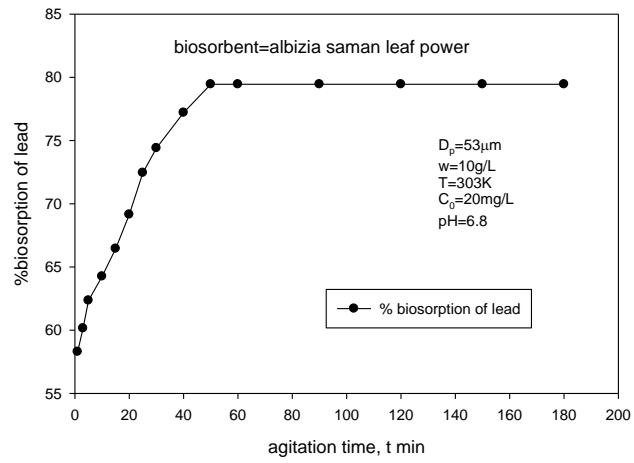

Fig. 1 Effect of agitation time on \% biosorption of lead

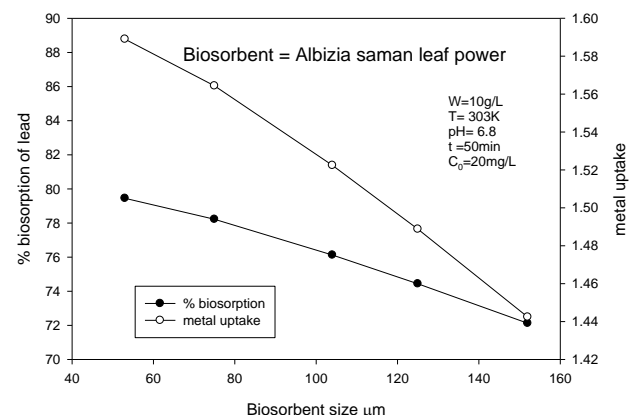

Fig. 2 Variations in \% biosorption of lead using biosorbent size:

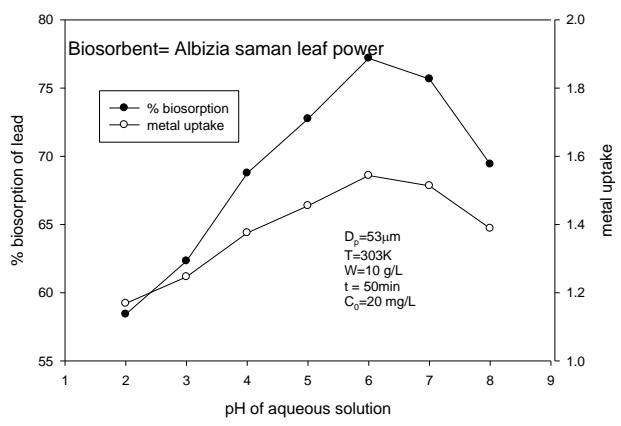

Fig. 3 Effect of pH on \% biosorption of lead 
IOSR Journal of Pharmacy

Vol. 2, Issue 3, May-June, 2012, PP.579-592

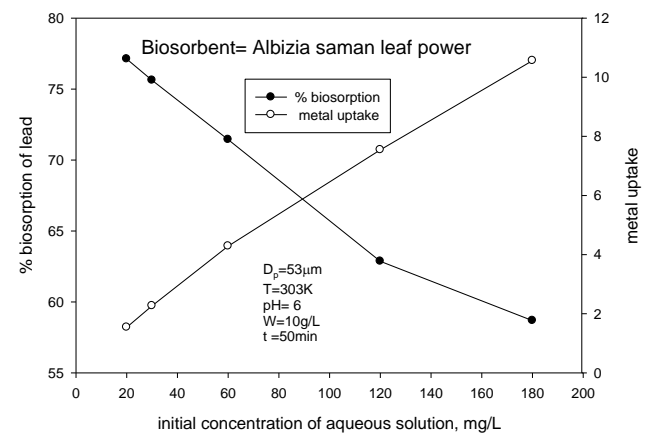

Fig. 4 Effect of initial concentration for the biosorption of lead

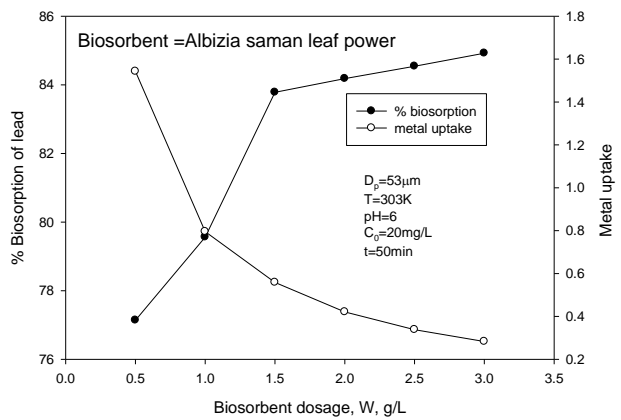

Fig. 5 Effect of biosorbent dosage on \% biosorption of lead

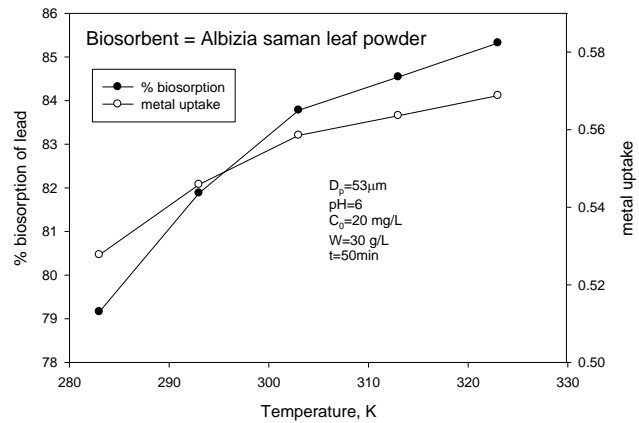

Fig. 6 Effect of temperature for the biosorption of lead 
IOSR Journal of Pharmacy

Vol. 2, Issue 3, May-June, 2012, PP.579-592

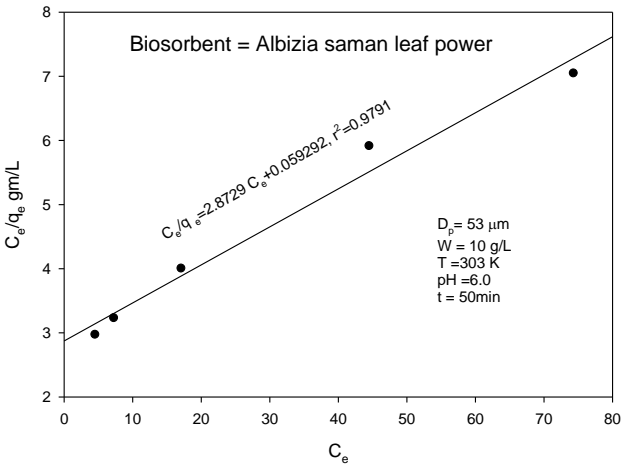

Fig. 7 Langmuir isotherm for biosorption of lead

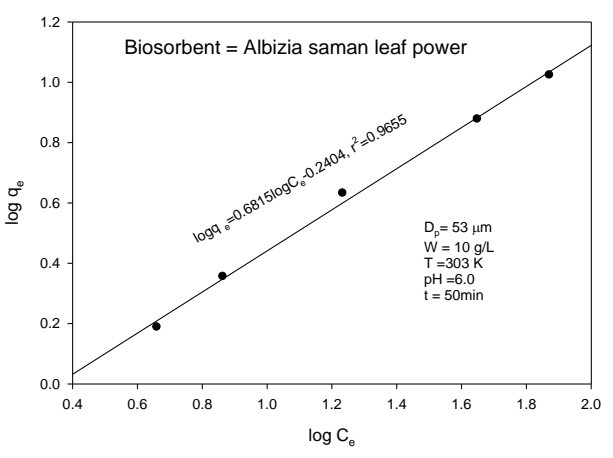

Fig. 8 Freundlich isotherm for biosorption of lead

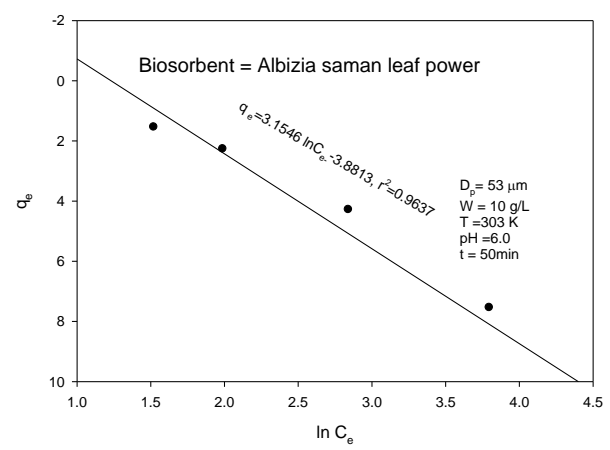

Fig. 9 Temkin isotherm for biosorption of lead 
IOSR Journal of Pharmacy

Vol. 2, Issue 3, May-June, 2012, PP.579-592

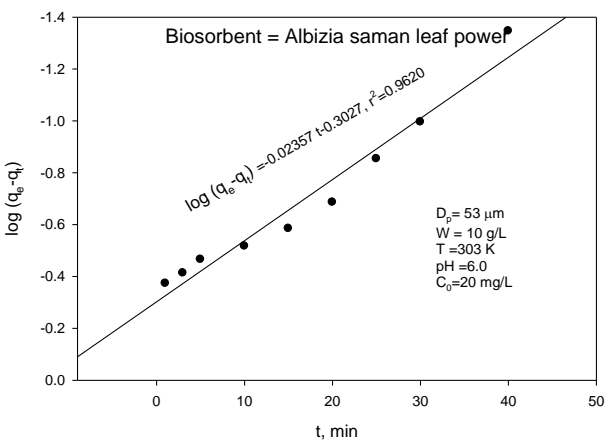

Fig. 10 First order kinetics for biosorption of lead

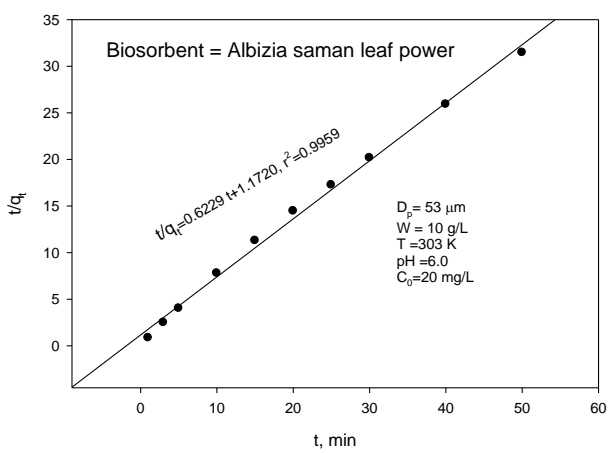

Fig. 11 Second order Kinetics for biosorption of lead

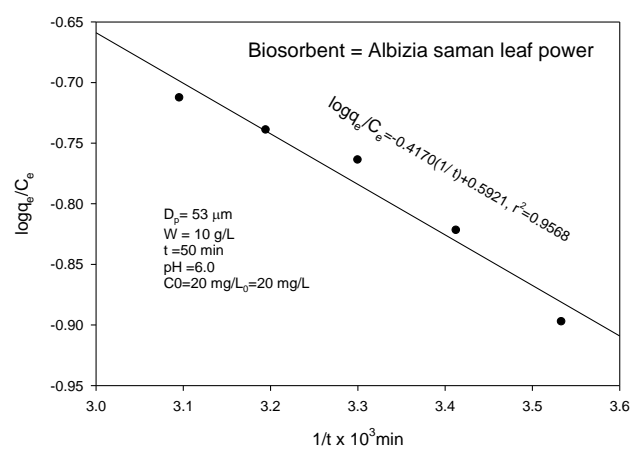

Fig. 12 Vant Hoff's plot for biosorption of lead 
IOSR Journal of Pharmacy

Vol. 2, Issue 3, May-June, 2012, PP.579-592

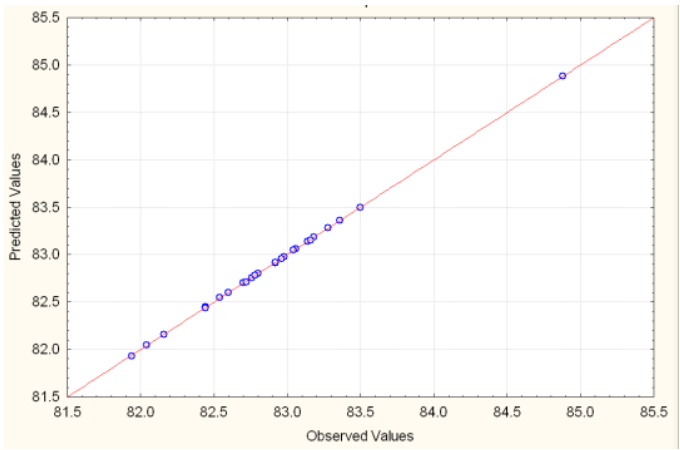

Fig. 13 Predicted vs Observed

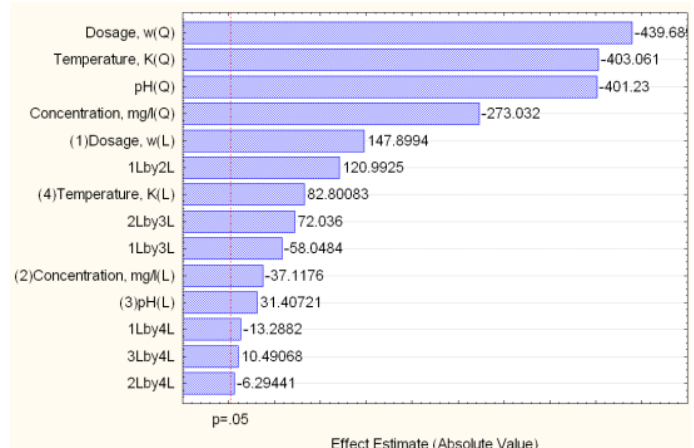

Fig. 14 Pareto Chart

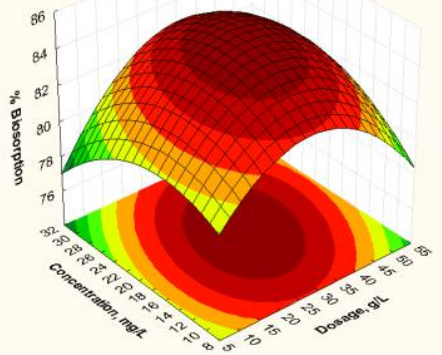

Fig. 15 Surface contour plot for the effects of dosage and initial concentration of lead on \% biosorption 
IOSR Journal of Pharmacy

Vol. 2, Issue 3, May-June, 2012, PP.579-592

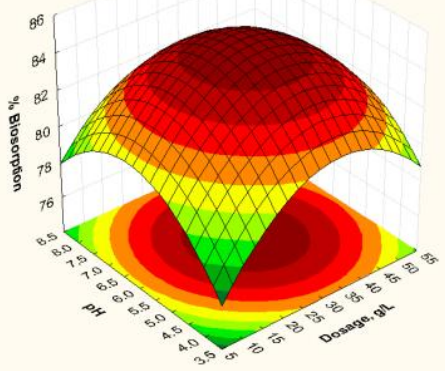

Fig. 16 Surface contour plot for the effects of dosage and $\mathrm{pH}$ on \% biosorption of lead

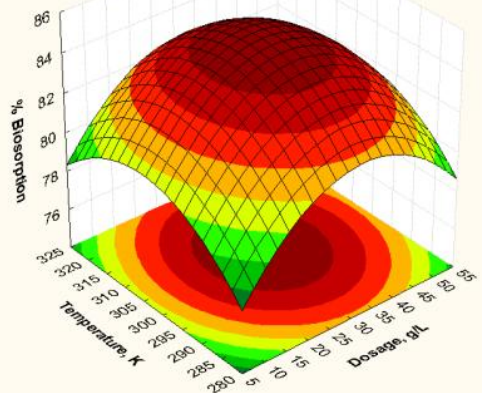

Fig. 17 Surface contour plot for the effects of dosage $\&$

Temperature on \% biosorption of lead

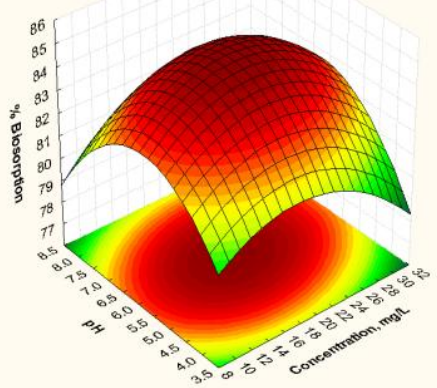

Fig. 18 Surface contour plot for the effects of initial concentration and $\mathrm{pH}$ on $\%$ biosorption of lead 
IOSR Journal of Pharmacy

Vol. 2, Issue 3, May-June, 2012, PP.579-592

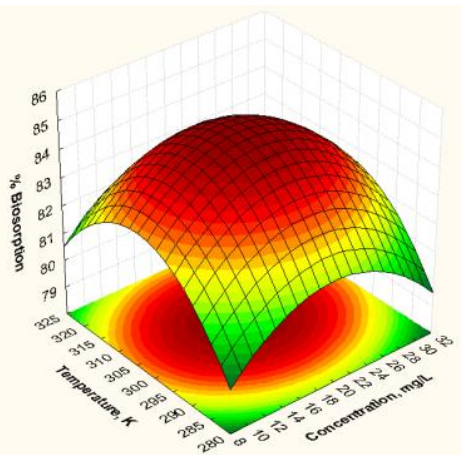

Fig. 19 Surface contour plot for the effects of initial concentration and Temperature on \% biosorption of lead

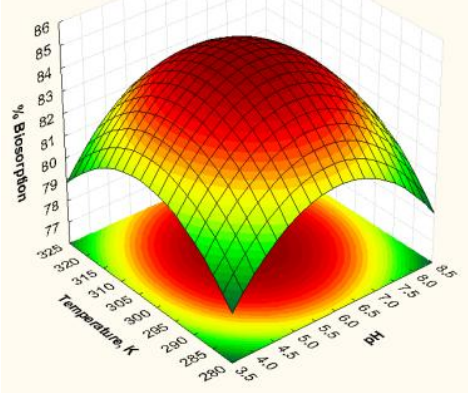

Fig. 20 Surface contour plot for the effects of $\mathrm{pH}$ and Temperature on \% biosorption of lead

TABLE-1

Levels of different process variables in coded and un-coded form for \% biosorption of lead using Albizia saman leaf powder

\begin{tabular}{|c|c|c|c|c|c|c|}
\hline Var & Name & \multicolumn{5}{|c|}{ Range and levels } \\
\cline { 3 - 7 } & -2 & -1 & 0 & 1 & 2 \\
\hline $\mathrm{X}_{1}$ & $\begin{array}{c}\text { Biosorbent dosage, } \\
\text { w, g/L }\end{array}$ & 10 & 20 & 30 & 40 & 50 \\
\hline $\mathrm{X}_{2}$ & $\begin{array}{c}\text { Initial concentration, } \\
\text { Co, } \mathrm{mg} / \mathrm{L}\end{array}$ & 10 & 15 & 20 & 25 & 30 \\
\hline $\mathrm{X}_{3}$ & $\begin{array}{c}\text { pH of aqueous } \\
\text { solution }\end{array}$ & 4 & 5 & 6 & 7 & 8 \\
\hline $\mathrm{X}_{4}$ & Temperature, $\mathrm{T}, \mathrm{K}$ & 283 & 293 & 303 & 313 & 323 \\
\hline
\end{tabular}


IOSR Journal of Pharmacy

Vol. 2, Issue 3, May-June, 2012, PP.579-592

TABLE-2 Results from CCD for lead biosorption by Albizia saman leaf powder
\begin{tabular}{|c|c|c|c|c|c|c|}
\hline Runs & $\mathrm{X}_{1}, \mathrm{~W}$ & $\mathrm{X}_{2}, \mathrm{C}_{\mathrm{o}}$ & $\mathrm{X}_{3}, \mathrm{pH}$ & $\mathrm{X}_{4}, \mathrm{~T}$ & Experimental & Predicted \\
\hline 1 & -1.00 & -1.00 & -1.00 & -1.00 & 82.70 & 82.70 \\
\hline 2 & -1.00 & -1.00 & -1.00 & 1.00 & 82.98 & 82.98 \\
\hline 3 & -1.00 & -1.00 & 1.00 & -1.00 & 82.72 & 82.71 \\
\hline 4 & -1.00 & -1.00 & 1.00 & 1.00 & 83.06 & 83.05 \\
\hline 5 & -1.00 & 1.00 & -1.00 & -1.00 & 81.94 & 81.93 \\
\hline 6 & -1.00 & 1.00 & -1.00 & 1.00 & 82.16 & 82.15 \\
\hline 7 & -1.00 & 1.00 & 1.00 & -1.00 & 82.44 & 82.44 \\
\hline 8 & -1.00 & 1.00 & 1.00 & 1.00 & 82.76 & 82.75 \\
\hline 9 & 1.00 & -1.00 & -1.00 & -1.00 & 82.96 & 82.96 \\
\hline 10 & 1.00 & -1.00 & -1.00 & 1.00 & 83.14 & 83.13 \\
\hline 11 & 1.00 & -1.00 & 1.00 & -1.00 & 82.54 & 82.54 \\
\hline 12 & 1.00 & -1.00 & 1.00 & 1.00 & 82.80 & 82.80 \\
\hline 13 & 1.00 & 1.00 & -1.00 & -1.00 & 83.04 & 83.04 \\
\hline 14 & 1.00 & 1.00 & -1.00 & 1.00 & 83.18 & 83.18 \\
\hline 15 & 1.00 & 1.00 & 1.00 & -1.00 & 83.16 & 83.15 \\
\hline 16 & 1.00 & 1.00 & 1.00 & 1.00 & 83.36 & 83.36 \\
\hline 17 & -1.00 & 0.00 & 0.00 & 0.00 & 82.04 & 82.04 \\
\hline 18 & 2.00 & 0.00 & 0.00 & 0.00 & 82.92 & 82.91 \\
\hline 19 & 0.00 & -2.00 & 0.00 & 0.00 & 83.50 & 83.49 \\
\hline 20 & 0.00 & 2.00 & 0.00 & 0.00 & 83.28 & 83.28 \\
\hline 21 & 0.00 & 0.00 & -2.00 & 0.00 & 82.60 & 82.59 \\
\hline 22 & 0.00 & 0.00 & 2.00 & 0.00 & 82.78 & 82.78 \\
\hline 23 & 0.00 & 0.00 & 0.00 & -2.00 & 82.44 & 82.43 \\
\hline 24 & 0.00 & 0.00 & 0.00 & 2.00 & 82.92 & 82.92 \\
\hline 25 & 0.00 & 0.00 & 0.00 & 0.00 & 84.88 & 84.88 \\
\hline 26 & 0.00 & 0.00 & 0.00 & 0.00 & 84.88 & 84.88 \\
\hline 27 & 0.00 & 0.00 & 0.00 & 0.00 & 84.88 & 84.88 \\
\hline 28 & 0.00 & 0.00 & 0.00 & 0.00 & 84.88 & 84.88 \\
\hline 29 & 0.00 & 0.00 & 0.00 & 0.00 & 84.88 & 84.88 \\
\hline 30 & 0.00 & 0.00 & 0.00 & 0.00 & 84.88 & 84.88 \\
\hline & & & & & & \\
\hline
\end{tabular}

Table-3

ANOVA of lead biosorption for entire quadratic model

\begin{tabular}{|c|c|c|c|c|c|}
\hline Source of variation & SS & df & $\begin{array}{c}\text { Mean } \\
\text { square(MS) }\end{array}$ & F-value & P > F \\
\hline Model & 24.3289 & 14 & 1.737778 & 33852.82 & 0.0000 \\
\hline Error & 0.00077 & 15 & 0.0000513 & & \\
\hline Total & 24.32967 & & & & \\
\hline
\end{tabular}

Df- degree of freedom; SS- sum of squares; F- factor F; P- probability. $R^{2}=0.99997 ; R^{2}($ adj):0.99994 
IOSR Journal of Pharmacy

Vol. 2, Issue 3, May-June, 2012, PP.579-592

Table-4

\begin{tabular}{|c|c|c|c|c|}
\hline Terms & $\begin{array}{l}\text { Regression } \\
\text { coefficient }\end{array}$ & $\begin{array}{c}\text { Standard error of } \\
\text { the coefficient }\end{array}$ & $\mathrm{t}$-value & P-value \\
\hline Mean/Intercept & -452.007 & 1.335753 & -338.391 & 0.000000 \\
\hline Dosage, w, g/L (L) & 0.429 & 0.005629 & 76.293 & 0.000000 \\
\hline Dosage, w, g/L (Q) & -0.006 & 0.000014 & -439.689 & 0.000000 \\
\hline Conc, $\mathrm{Co}, \mathrm{mg} / \mathrm{L}(\mathrm{L})$ & 0.369 & 0.011310 & 32.663 & 0.000000 \\
\hline Conc, Co, mg/L (Q) & -0.015 & 0.000055 & -273.032 & 0.000000 \\
\hline pH (L) & 5.846 & 0.057298 & 102.035 & 0.000000 \\
\hline pH (Q) & -0.548 & 0.001365 & -401.230 & 0.000000 \\
\hline Temperature, T, K (L) & 3.347 & 0.008391 & 398.867 & 0.000000 \\
\hline Temperature, T, K (Q) & -0.006 & 0.000014 & -403.061 & 0.000000 \\
\hline $1 \mathrm{~L}$ by $2 \mathrm{~L}$ & 0.004 & 0.000036 & 120.992 & 0.000000 \\
\hline $1 \mathrm{~L}$ by $3 \mathrm{~L}$ & -0.010 & 0.000179 & -58.048 & 0.000000 \\
\hline $1 \mathrm{~L}$ by $4 \mathrm{~L}$ & -0.000 & 0.000018 & -13.288 & 0.000000 \\
\hline $2 \mathrm{~L}$ by $3 \mathrm{~L}$ & 0.026 & 0.000357 & 72.036 & 0.000000 \\
\hline $2 \mathrm{~L}$ by $4 \mathrm{~L}$ & -0.000 & 0.000036 & -6.294 & 0.000014 \\
\hline $3 \mathrm{~L}$ by $4 \mathrm{~L}$ & 0.002 & 0.000179 & 10.491 & 0.000000 \\
\hline
\end{tabular}

\section{CONCLUSION}

Both Preliminary and finals experimental runs are carried out to find out the equilibrium, isotherms, kinetics and thermodynamic parameters for biosorption of lead from an aqueous solution using Albizia saman leaf powder. The analysis of the experimental and theoretical data results in the conclusions that the equilibrium agitation time for lead biosorption is 50 minutes. The \% biosorption of lead from an aqueous solution increased from 72.12 to $79.45 \%$ with a decrease in the particle size of the biosorbent from 152 to $53 \mu \mathrm{m}$ and increases from 77.14 to $83.78 \%$ with increase in biosorbent dosage from 10 to $30 \mathrm{~g} / \mathrm{L}$. With an increase in the initial concentration of lead in the aqueous solution (20 to $180 \mathrm{mg} / \mathrm{L}$ ), the percentage biosorption of lead from the aqueous solution is decreased from 77.12 to $58.68 \%$. Percentage biosorption of lead from the aqueous solution increased significantly with increase in $\mathrm{pH}$ from 2 to 6 (58.42 to $77.18 \%)$. Hereafter, percentage biosorption decreases for further increase in $\mathrm{pH}$ from 6 to 8 (77.18 to $69.42 \%)$. The maximum uptake capacity of 16.8656 $\mathrm{mg} / \mathrm{g}$ is obtained at a temperature of $303 \mathrm{~K}$. The present study involves the use of statistical experimental design to optimize process conditions for maximal biosorption of lead from aqueous solution using CCD involving RSM. The maximum biosorption of lead $(84.90612 \%)$ onto Albizia saman leaf powder is observed when the processing parameters are set as follows: $\mathrm{pH}=6.0250, \mathrm{w}=31.7191 \mathrm{~g} / \mathrm{L}, \mathrm{Co}=19.8996 \mathrm{mg} / \mathrm{L}$ and $\mathrm{T}=304.0673 \mathrm{~K}$. The kinetic studies showed that the biosorption of lead is better described by pseudo second order kinetics. The thermodynamic data depicted that \% biosorption of lead increased with increase in temperature up to some extent. 
IOSR Journal of Pharmacy

Vol. 2, Issue 3, May-June, 2012, PP.579-592

\section{REFERENCES}

[1] Prerna Ahuja, Rani Gupta, R.K. Saxena, Sorption and Desorption of Cobalt by Oscillatoria anguistissima, Current Microbiology Vol. 39, 1999, pp. 49-52

[2] Ahmet Çabuk, Tamer Akar, Sibel Tunali, Özge Tabak, Biosorption characteristics of Bacillus sp. ATS-2 immobilized in silica gel for removal of Pb(II), Journal of Hazardous Materials, Volume 136, Issue 2, 21, 2005, Pages 317-323

[3] Volesky, B., Removal and recovery of heavy metals by biosorption [C] Volesky B, ed. Biosorption of Heavy Metals (Boca Raton: CRC Press, 1990) 12-13.

[4] Volesky, B, Biosorption of Heavy Metals (CRC Press, Boca Raton 1990).

[5] Lo, W., Chua, H., Lam, K.H., Bi, S.P., A comparative in vestigation on the biosorption of lead by filamentous fungal biomass, Chemosphere 39, 1999, 2723-2736.

[6] Alaa H. Hawari, Catherine N. Mulligan, Biosorption of lead(II), cadmium(II), copper(II) and nickel(II) by anaerobic granular biomass, Bioresource Technology 97, 2006, 692-700.

[7] Ankit Balaria, Silke Schiewer, Assessment of biosorption mechanism for $\mathrm{Pb}$ binding by citrus pectin, Separation and Purification Technology 63, 2008, 577-581.

[8] Anushree Malik, Metal bioremediation through growing cells, Environment International 30, 2004, 261278.

[9] Arzu,Y.and Dursun,A., Comparative study on determination of the equilibrium, kinetic and thermodynamic parameters of biosorption of copper (II) and lead (II) ions onto pretreated Aspergillus niger, Biochem.Eng. J., 28, 2006, 187-195.

[10] Chandrasekhar K, Subramanian S, Modak JM, Natarajan KA, Removal of metals using an industrial biomass with reference to environmental control, Int J Miner Process 53, 1998, 107-120.

[11] K. Parvathi, R. Nareshkumar R. Nagendran, Biosorption of lead by Aspergillus niger and Saccharomyces cerevisiae, World J Microbiol Biotechnol 23, 2007, 671-676.

[12] R.N. Sylva, The environmental chemistry of copper (II) in aquatic systems, Water Res. 10, 1976, 789-792.

[13] O. Masala, E.J.L. McInnes, P. Obrien, Modelling the formation of granules: the influence of lead ions on calcium pyrophosphate precipitates, Inorg, Chim. Acta 339, 2002, 366-372.

[14] Goyal N, Jain SC, Banerjee, Comparative studies on the microbial adsorption of heavy metals, Adv Environ Res 7, 2003, 311-319.

[15] Sag, Y., D. Ozer and T. Kutsal, A comparative study of the biosorption of lead(II) ions to Z. ramigera and R. arrhizus, Process Biochem., 30, (2), 1995, 169-174.

[16] R.H.S.F. Vieira, B. Volesky, Biosorption: a solution to pollution, Int. Microbiol. 3, 2000, 17-24.

[17] I. Langmuir, The constitution and fundamental properties of solids and liquids. Part 1: Solids, J. Am. Chem. Soc., 38, 1916, 2221-2295.

[18] I. Langmuir, The adsorption of gases on plane surface of glass, mica and platinum, J. Am. Chem. Soc., 40, 1918, 1361-1403.

[19] H. Freundlich, Uber die adsorption in losungen (Adsorption in solution), Z. Phys. Chemie., 57, 1906, 384470.

[20] M.J Temkin and V Pyzhey, Recent modifications to Langmuir isotherms, Acta Physiochim., 12, 1940, $217-$ 222.

[21] S. Lagergren, On the theory of so called adsorption of dissolved substances, Handlingar, 24, 1898, 1-39.

[22] Y.S. Ho and G McKay, A Comparison of Chemisorption Kinetic Models Applied to Pollutant Removal on Various Sorbents, Process Safety and Environmental Protection, 6B, 1998, 332-340.

[23] Y.S. Ho and G. McKay, Pseudo-second order model for sorption processes, Process Biochemistry, 34, 1999, 451-465. 